\title{
PERLINDUNGAN KEBEBASAN BERPARTISIPASI DALAM PROSES PEMBENTUKAN PERATURAN DAERAH BERDASARKAN UNDANG-UNDANG NOMOR 12 TAHUN 2011 TENTANG PEMBENTUKAN PERATURAN PERUNDANG-UNDANGAN DITINJAU DARI PERSPEKTIF HAK ASASI MANUSIA
}

\author{
Oleh : \\ Putu Ayu Anastasia Wierdarini ${ }^{1}$
}

\begin{abstract}
This Law research is about the protection of liberty to participate in the process of establishing regional regulation based on Law Number 12 Year 2011 on the Establishment of legislation which is reviewed fromthe perspective of human rights. This research is using the normative research method with background based on the lack and ineffectiveness of the public participation towards the process of formation of the local regulations in terms of the perspective of human rights. The analysis and discussion outlined the legal basis of the regulation of public participation in term of any form of public participation that can be done as in the end the public society would indeed be the object of the regulation. With the enactment of Law No. 32 year 2004 on Regional Government, using the principle of regional autonomy, the regional has the authority and responsibility to manage and coordinate the various interests of the community in accordance with the legislation. Therefore, the society has a significant and important role towards the preparation of a legal product to accommodate the interests and needs of the community and support all activities in the community itself. However, there are still problems with the effectiveness of the opportunity given to the public to participate in producing a legal product that is fully favor the interests of the community at large.
\end{abstract}

Keywords : Public Participation, Regional Rules, Human Rights.

\begin{abstract}
Abstrak
Penulisan hukum ini berjudul tentang perlindungan kebebasan berpartisipasi dalam proses pembentukan peraturan daerah berdasarkan Undang-Undang Nomor 12 Tahun 2011 tentang Pembentukan Peraturan Perundang-undangan ditinjau dari perspektif hak asasi manusia. Penelitian hukum ini menggunakan penelitian hukum normatif, adapun yang menjadi latar belakang penelitian adalah tidak berlaku secara efektif dan maksimal partisipasi masyarakat dalam proses pembentukan peraturan daerah ditinjau dari perspektif hak asasi manusia. Di dalam analisa dan pembahasan diuraikan dasar hukum pengaturan dari partisipasi publik ini juga dalam bentuk apa saja partisipasi masyarakat dapat dilakukan, karena pada akhirnya masyarakatlah sebagai objek dari peraturan tersebut. Dengan diberlakukannya Undang-Undang No. 32 Tahun 2004 Tentang
\end{abstract}

Mahasiswa Program Magister (S2) Ilmu Hukum Universitas Udayana, Denpasar, Bali, Alamat : Jalan Dahlia No. 9, Denpasar, Email: putu.thesa@gmail.com 
Pemerintahan Daerah, dengan menggunakan prinsip otonomi daerah, daerah memiliki kewenangan dan tanggung jawab dalam mengurus dan mengkoordinir berbagai kepentingan masyarakatnya sesuai dengan peraturan perundangundangan. Untuk itu maka sangatlah penting peran serta masyarakat terhadap penyusunan suatu produk hukum untuk mengakomodir berbagai kepentingan dan kebutuhan masyarakat dan menunjang segala aktivitas dalam masyarakat itu sendiri.Namun, hal yang masih mengganjal adalah belum efektif nya kesempatan dalam berpartisipasi ini sehingga banyak produk hukum yang dihasilkan belum berpihak sepenuhnya pada kepentingan masyarakat.

\section{Kata Kunci : Partisipasi Publik, Peraturan Daerah, Hak Asasi Manusia}

\section{PENDAHULUAN}

\subsection{Latar Belakang}

Demokrasi

merupakan

sebuah asas kenegaraan yang dalam pelaksanaannya diantara Negaranegara saling berbeda.Meskipun demikian, semangat demokrasi tetap dijunjung tinggi tiap Negara tersebut. Gagasan demokrasi memberikan konsep baru yaitu negara hukum yang didalamnya terdapat prinsipprinsip perlindungan Hak Asasi Manusia (HAM). Bila dikaitkan dengan demokrasi, perlindungan HAM merupakan ekses dari adanya demokrasi yang menjamin kebebasan berpolitik. Sedangkan hak asasi manusia mengandung prinsipprinsip kebebasan berpendapat dan berpolitik. Agar sebuah masyarakat dianggap benar-benar demokratis, harus ada perlindungan dalam derajat tinggi untuk pengeluaran ide-ide dalam bentuk yang terpublikasikan, apakah mediumnya surat kabar, majalah, buku, pamflet, film, televisi, atau yang paling mutakhir internet. Kebebasan berpendapat seperti yang sering didengung-dengungkan akhirakhir ini, pasca reformasi, dimana seolah-olah membawa angin segar bagi masyarakat dalam mengeluarkan pikirannya serta gagasannya, bahkan melakukan kritikan kepada pemerintah. Kebebasan berpartisipasi dalam proses pembentukan peraturan perundang-undangan mendapatkan tempat tersendiri dalam proses demokrasi dan reformasi yang tengah berjalan di Indonesia saat ini. Pada tanggal 12 Agustus 2011, Pemerintah secara resmi mengundangkan UndangUndang Nomor 12 Tahun 2011 tentang Pembentukan Peraturan PerundangUndangan. Dalam Pasal 96 UndangUndang No 12 Tahun 2011 diatur mengenai partisipasi masyarakat dalam pembentukan peraturan perundangundangan.

Partisipasi masyarakat dalam proses pembentukan suatu peraturan perundang-undangan merupakan suatu hal yang substansial dalam mencegah adanya penyalahgunaan wewenang yang diatur dalam undangundang. Meskipun produk hukum yang dihasilkan belum tentu dapat berlaku secara efektif di masyarakat namun setidaknya upaya antisipasi telah ditempuh oleh lembaga legislasi 
dalam setiap penyusunan suatu produk hukum.

Sementara itu dalam penerapannya seringkali hal tersebut tidak dapat terlaksana secara maksimal, misalkan bentuk peran serta masyarakat seperti apa yang diinginkan oleh pemerintah karena pada akhirnya masyarakat sebagai objek dari peraturan tersebut. Dengan diberlakukannya Undang-Undang No 23 Tahun 2014 Tentang Pemerintahan Daerah, dengan menggunakan prinsip otonomi daerah, daerah memiliki kewenangan dan tanggung jawab dalam mengurus dan mengkoordinir berbagai kepentingan masyarakatnya sesuai dengan peraturan perundangundangan. Untuk itu maka sangatlah penting peran serta masyarakat terhadap penyusunan suatu produk hukum untuk mengakomodir berbagai kepentingan dan kebutuhan masyarakat dan menunjang segala aktivitas dalam masyarakat itu sendiri.Namun. hal yang masih mengganjal adalah belum efektif nya kesempatan dalam berpartisipasi ini sehingga banyak produk hukum yang dihasilkan belum berpihak sepenuhnya pada kepentingan masyarakat.

Terkait dengan permasalahan tersebut.maka penulis mengangkat judul "Perlindungan Kebebasan Berpartisipasi Dalam Proses Pembentukan Peraturan Daerah Berdasarkan Undang-Undang Nomor 12 Tahun 2011 Tentang Pembentukan Peraturan Perundang-Undangan Ditinjau Dari Perspektif Hak Asasi Manusia".

\subsection{Perumusan Masalah}

1. Bagaimana pengaturan HAM terkait partisipasi masyarakat dalam proses pembentukan peraturan daerah?

2. Bagaimanakah bentuk partisipasi masyarakat dalam proses pembentukan Peraturan Daerah?

\subsection{Tujuan Penelitian}

Dalamsubbagianinimenjabarkan hal yang ingin peneliti capai terkait dengan partisipasi masyarakat dalam proses pembentukan peraturan daerah. Bertujuan untuk memperoleh analisa hukum yang diperlukan untuk menjawab permasalahan hukum diantaranya :

1. Untuk memperoleh dan menganalisa berbagai peraturan yang masih berlaku yang mengatur tentang peran serta publikdalamprosespembentukan peraturan daerah yang mana hal tersebut dapat dijadikan dasar hukum oleh masyarakat untuk aktif berpartisipasi dalam proses penyusunan suatu produk hukum.

2. Untuk mengetahui dan menganalisa berbagai bentuk dan media dalam berpartisipasi oleh masyarakat terhadap proses pembentukan peraturan daerah. 


\section{METODE PENELITIAN}

\subsection{Jenis Penelitian}

Pada penelitian ini, jenis penelitian yang digunakan adalah penelitian hukum normatif. Penelitian ini menggunakan teknis pendekatan peraturan perundang-undangan dan pendekatan analisis konsep hukum. ${ }^{2}$

\subsection{Jenis Pendekatan}

Penelitian ini mengacu pada jenis penelitian normative yang mempergunakan pendekatan perundang-undangan, hal mana dipergunakan untuk menganalisa peraturan hukum dan sumber bahan hukum sekunder seperti buku-buku yang dapat menjawab permasalahan terkait.

\subsection{Sumber Bahan Hukum}

1. Bahan hukum primer berupa peraturan perundang-undangan yang didalamnya diatur tentang kebebasan berpartisipasi dalam proses pembentukan peraturan perundang-undangan khususnya peraturan daerah yakni UndangUndang Dasar Negara Republik Indonesia Tahun 1945, UndangUndang No.9Tahun 1998 tentang Kemerdekaan Menyampaikan Pendapat Di Muka Umum, Undang-Undang No. 39 Tahun 1999 tentang Hak Asasi Manusia, Undang-Undang No. 12 Tahun 2005 tentang Pengesahan

H. Zainudin Ali, 2010, Metode Penelitian Hukum, Sinar Grafika, Jakarta, hlm. 24
Internasional Covenant On Civil And Political Rights (Covenant Internasional Tentang Hak-Hak Sipil Dan Politik), UndangUndang Nomor 12 Tahun 2011 Tentang Pembentukan Peraturan Perundang-Undangan.

2. Bahan hukum sekunder, yakni terdiri dari berbagai literature yang terkait dengan pokok penelitian ini.

\subsection{Teknik Pengumpulan Bahan Hukum \\ Penelitian ini mempergunakan} metode pengumpulan berbagai peraturan hukum, buku-buku yang terkait dengan penelitian ini, yang kemudian dianalisa dan dikolaborasikan dengan permasalahan hukum dalam penelitian ini.

\subsection{Teknik Pengolahan dan Analisis Bahan Hukum \\ Penelitian ini mempergunakan} teknik analisis menggunakan teknik deskripsi, teknik argumentasi, teknik sistematisasi.

\section{HASIL DAN PEMBAHASAN \\ 3.1 PengaturanKebebasan Partisi- pasi Masyarakat Dalam Proses Pembentukan Peraturan Per- undang-undangan}

Fokus HAM adalah tentang kehidupan dan martabat manusia.Hakhak yang menekankan bahwa manusia bebas memilih tindakan mereka, yang pada dasarnya merupakan manifestasi dari martabat manusia, membentuk 
inti yang mendasari pembentukan sejumlah hak-hak lainnya. Hak-hak politik (hak untuk memilih, kesetaraan dalam mengakses pelayanan publik, dan sebagainya. ${ }^{3}$

Walaupun berkali-kali dikatakan sebagai tidak bisa dibagi-bagi, menurut teori tradisional, hak-hak politik sipil dan hak-hak sosial ekonomi merupakan dua kategori hak yang jelas berbeda, yang, sesuai dengan sifatnya, tidak bisa diperlakukan sama dan tidak bisa diberlakukan dengan penekanan yang sama seperti yang dinyatakan pada bagian awal teks dari Deklarasi Vienna. Alasannya ada tiga. Pertama, landasan teori dari hak-hak tersebut adalah tidak sama; kedua, di sekitar dari hak-hak tersebut ada ideologi-ideologi yang berbeda; dan ketiga dan merupakan alasan yang paling penting, struktur normatif dari hak-hak tersebut demikian juga karakternya berbeda-beda. Perbedaanperbedaan ini tergantung dan terkait satu sama lain, dan dengan caranya masing-masing mempengaruhi persepsi kedua kelompok hak tersebut yang mengakibatkan adanya sistem supervisi yang mengakibatkan tidak diberikannya proteksi yang sama. Sejauh menyangkut hak-hak politik sipil dan hak-hak sosial ekonomi, ada beberapa orang penulis yang telah memberikan penekanan bahwa hakhak azasi manusia itu telah berkembang pada generasi-generasi yang mulai

Manfred Nowak, 2003, Pengantar Rezim Hak Asasi Manusia International, (Alih Bahasa oleh Sri Sulastini), MartinusNijhoff Publisher, English, p.1-2. dengan hak kebebasan generasi pertama klasik yang muncul pada abad ke 18 seperti Konstitusi Amerika Serikat dari tahun 1787 dan Deklarasi Perancis tentang Hak-Hak Asasi Manusia dan Warganegara dari tahun 1789; kebebasan pribadi, kebebasan berbicara, kebebasan berserikat dan berkumpul, kebebasan beragama, dan lain-lain. Kemudian, pada abad ke 19, kebebasan-kebebasan ini ditambahkan sejumlah hak-hak generasi kedua yang muncul dari skema kesejahteraan Bismack untuk para pekerja Jerman dan kemudian ditegakan pada awal abad ke 20 dengan pengakuan hakhak terhadap perumahan, pelayanan kesehatan dan kesejahteraan, pendidikan, dan lain-lain. Hak-hak generasi ketiga mengacu pada hakhak yang tidak diakui dengan jelas oleh konvensi hak-hak asasi manusia yang asli dari tahun 1950-an dan 1960an dan meliputi, sebagai contoh, hak akan hak-hak pembangunan dan lingkungan.

Deklarasi Universal Hak Asasi Manusia termasuk daftar pendek tapi substansial menyangkut hak-hak yang telah dijabarkan lebih lanjut, dengan penambahan sederhana, dalam berbagai perjanjian selanjutnya, terutama pada tahun 1966 Covenant Internasional Hak Asasi Manusia. ${ }^{4}$

Hampir semuanya berargumentasi bahwa fondasi-fondasi hak-hak asasi manusia merupakan

Jack Donnely, 2003, Universal Human Rights in Theory and Practice 2" Edition, Cornell University Press, New York, p.22. 
sumber moral dan oleh karena itu sumber legitimasi politik dari hakhak azazi manusia. Di satu sisi ada consensus internasional bahwahak-hak asasi manusia sedang tumbuh, di lain pihak consensus tentang fondasinya tidak ada perkembangan. Di samping itu, tidak ada perkembangan kapan pelanggarannya merupakan imperative politis. Perjuangan dalam penegakan hak asasi manusia pada dasarnya merupakan bagian dari sejarah di berbagai negara, termasuk Indonesia. Oleh karenanya, keberadaan dan perkembangan budaya Indonesia yang "berkembang sesuai dengan watak bangsanya" juga tidak lepas dari pengaruh dan garis singgung dengan budaya asing, namun HAM bukan merupakan komoditas import. Konvensi tentang hak sipil dan politik tertuang dalam Convenant on Civil and Politic Rights (ICCPR). Menurut istilah Komisi Hukum Internasional, hak sipil dan politik menuntut tanggung jawab Negara dalam bentuk obligation of conduct. ICCPR adalah hak negative yang termasuk hak-hak non deragahle (hak absolute) yakni hak hidup, bebas dari perbudakan, penyiksaan, penahanan (karena utang), pidana berlaku surut, hak manusia sebagai subyek hukum, dan hak manusia dalam kebebasan berfikir, dan hakhak deragable, yakni hak berkumpul, hak berserikat, dan hak kebebasan menyatakan pendapat. ${ }^{5}$

$5 \quad$ Masyhur Effendi dan TaufaniSukmanaEvandri, 2007, HAM Dalam Dimensi/Dinamika Yuridis, Sosial, Politik, Ghalia Indonesia, Bogor, hlm. 138.
Memperhatikan hukum positif suatu Negara, tidak dapat dilepaskan dengan sistem hukum yang berlaku di Negara tersebut. Oleh karena itu, dasar Negara Pancasila dan Pembukaan Undang-Undang Dasar Tahun 1945 mengindikasikan Indonesia adalah Negara demokrasi, menjunjung tinggi supremasi hukum, serta menghormati/ menjunjung tinggi hak asasi manusia. Terkait dengan kebebasan dalam keikutsertaan masyarakat dalam proses penyusunan peraturan hukum dalam hal ini dimaksudkan memberikan saran atau pendapatnya, terdapat dalam beberapa peraturan perundangundangan yakni:

1. Undang-Undang Dasar Negara Republik Indonesia Tahun 1945, Pasal 28 dan Pasal 28 E Ayat (3).

2. Undang-Undang No. 9 Tahun 1998 tentangKemerdekaan Menyampaikan Pendapat Di Muka Umum Pasal 2.

3. Undang-Undang No. 39 Tahun 1999 tentang Hak Asasi Manusia Pasal 23 Ayat

4. Undang-Undang No. 12 Tahun 2005 tentang Pengesahan Internasional Covenant On Civil And Political Rights (Covenant Internasional Tentang HakHak Sipil Dan Politik). Dalam Undang-Undang ini tidak diatur lebih lanjut mengenai hakhak sipil dan politik yang ada di Indonesia, sebab UndangUndang ini meratifikasi secara 
keseluruhan dari Covenant Internasional tentang Hak Sipil dan Politik. Jadi apapun yang menjadi substansi dalam Covenant Internasional Hak Sipil dan Politik juga merupakan isi dari Undang-Undang No. 12 Tahun 2005 ini dan merupakan bagian yang tak terpisahkan, seperti yang tertulis dalam Undang-Undang tersebut, sehingga pengaturan mengenai kebebasan menyatakan pendapat diatur dalam Undang-Undang Nomor 12 Tahun 2005 Pasal 19 Ayat 1 dan 2.

5. Undang-Undang

Nomor

12 Tahun 2011 Tentang

Pembentukan Peraturan

Perundang-Undangan Pasal 96.

3.2 Bentuk Partisipasi Masyarakat

Dalam Proses Pembentukan Peraturan Daerah

Sebelum dibahas lebih lanjut mengenai model partisipasi masyarakat tersebut, ada baiknya sedikit penulis paparkan dari sudut pandang sosiologi hukum mengenai konsep dari turut campur masyarakat secara aktif di bidang hukum serta efektifitas dari berlakunya hukum tersebut. Masyarakat bukanlah pihak yang pasif, tetapi sebagai pihak yang menentukan bagaimana hukum itu akan dipakai. Dengan demikian hukumdisini bukanlah suatu logika yang ditarik dari peraturan, namun aktivitas masyarakat dalam menggunakan atau tidak menggunakan hukum tersebut.Oleh OliverWendell Holmes $^{6}$ keadaan tersebut diutarakan dengan sangat bagus yang kemudian dikenal dengan Holmesian Dictum. Penggunaan hukum oleh masyarakat merupakan wilayah sosiologis, dimana masyarakat memberi pemaknaan sendiri terhadap hukum dan itulah yang mereka jalankan.

Terkait dengan Pasal 96 UndangUndang No. 12 Tahun 2011 Tentang Pembentukan Peraturan Perundangundangan, disini dapat dinilai efektifitas pelaksanaan peran serta masyarakat dalam proses pembentukan Peraturan Daerah. Jika yang akan kita kaji adalah efektivitas perundangundangan, beberapa faktor harus dikaji untuk menguji keefektifitasan dari suatu peraturan perundang-undangan, yakni:

a. Pemahaman tentang isi dari peraturan perundang-undangan itu sendiri

b. Bagaimana cara dalam memperoleh pemahaman tersebut

c. Lembaga Negara dalam kaitan dengan ruang lingkup perundang-undangan di dalam masyarakat

d. Proses kelahiran dari suatu peraturan perundang-undangan, dimana diharapkan tidak lahir secara tidak hati-hati demi

SatjiptoRaharjo, 2010, Sosiologi Hukum Perkembangan Metode dan Pilihan Masalah, Genta Publishing, Yogyakarta, hlm. 121. 
kepentingan sesaat, yang memiliki kualitas tidak baik dan tidak relevan dengan apa yang dibutuhkan oleh masyarakatnya. $^{7}$

Dalam penerapan keharusan adanya partisipasi masyarakat sesuai amanat dalam TJU No. 12 Tahun 2011 itu, terlebih dahulu untuk melihat pengertian dari konsep partisipasi masyarakat tersebut.Seorang filsuf bernama Cicero yang sangat terkenal dengan adagiumnya, ubi societas $i b i$ ius, Bahwa hukum itu dibentuk oleh, dan diberlakukan untuk masyarakat. Partisipasi rakyat terkait erat dengan demokrasi. Pembahasan yang lebih umum tentang kemungkinan partisipasi orang awam dalam proses-proses dan institusi-institusi hukum menimbulkan masalah-masalah teoritis yang sudah sering ditemui mengenai partisipasi dalam organisasi formal.Partisipasi jarang bersifat demokratisasi dalam pengertian fundamental. ${ }^{8}$

Dalam proses penyusunan suatu peraturan perundang-undangan, terdapat suatu interaksi yang terjadi, yang melibatkan berbagai pihak pemangku kepentingan yakni pemerintah/pemerintah

7 Achmad Ali, 2009, Menguak Teori Hukum (Legal Theory) dan Teori Peradilan (Judicial Prudence) Termasuk Interpretasi UndangUndang (Legisprudence), Prenada Media Group, Jakarta hlm. 378.

8 Roger Cotterrell, 2012, Sosiologi Hukum TheSosiology of Law, Diterjemahkan oleh NarulitaYusron. Nusa Media, Bandung, hlm. 426. daerah, lembaga sosial di dalam masyarakat, akademisi, kalangan professional, organisasi-organisasi kemasyarakatan dan berbagai lapisan masyarakat pemangku kepentingan. Mereka yang secara emosional, secara akademisi mungkin memiliki kepentingan yang sama dan berusaha untuk memperjuangkan berbagai masalah yang dihadapi dan dicarikan pemecahannya.

Dalam penyusunan suatu peraturan daerah, dapat bertitik tolak dari adanya suatu partisipasi masyarakat dan mereka yang memiliki kepentingan terhadap peraturan daerah tersebut, yang bertujuan untuk menghasilkan masukanmasukan serta pandangan-pandangan yang berguna dalam meningkatkan kualitas pengambilan keputusan. Dengan melibatkan banyak pemangku kepentingan apalagi dapat melibatkan masyarakat yang akan terkena dampak langsung atas suatu peraturan tersebut, para pengambil keputusan dapat memperoleh berbagai pengalaman, kebutuhan dan penghargaan dari berbagai elemen masyarakat, untuk kemudian dituangkan dalam suatu konsep demi kesempurnaan suatu produk hukum yang dihasilkan. ${ }^{9}$

Partisipasi publik yang dimaksudkan dalam penelitian ini adalah terkait dengan peran serta berbagai elemen masyarakat diluar

Mahendra Putra Kurnia. dkk, 2007, Pedoman Naskah Akademik PerdaPartisipatif, Kreasi Total Media, Yogyakarta. hlm. 71. 
pemerintah daerah dan DPRD dalam menyusun dan membentuk rancangan peraturan daerah. Dapat terbagi dalam dua elemen partisipan yakni : pertama, dari unsur pemerintahan diluar DPRD dan pemerintah daerah seperti lembaga-lembaga Negara lainnya yakni kepolisian, kejaksaan, dari unsur pengadilan, perguruan tinggi. Kedua, darielemenmasyarakat, baikindividual maupun organisasi social seperti LSM maupun elemen masyarakat yang memiliki keahlian ataupun pengalaman terkait. Adapun peran serta berbagai pihak diluar DPRD dan Pemerintah Daerah sangatlah penting yakni untuk memperoleh berbagai masukan, pengetahuan, pengalaman dari berbagai elemen masyarakat tersebut, untuk menjamin perda sesuai dengan permasalahan nyata yang ada di dalam masyarakat,untukmenumbuhkan sikap bertanggungjawab dan menjunjung tinggi kepatuhan akan peraturan yang telah dibuat bersama tersebut. ${ }^{10}$

Dalam pelaksanaan urusan pemerintahan, khususnya dalam proses penyusunan Peraturan Daerah, partisipasimasyarakat sangatbervariasi tergantung kondisi dari masyarakat itu sendiri. kondisi masyarakat dan lingkungannya. Bentuk-bentuk partisipasi yang dilakukan oleh berbagai elemen masyarakat yang disalurkan demi kesempurnaan suatu produk peraturan perundangundangan sangatlah dipengaruhi oleh

10 Bagir Manan, 2001, Menyongsong Fajar Otonomi Daerah, PSH Fak. Hukum UII, Yogyakarta, hlm. 85-86. kualitas dari sumber daya manusia itu sendiri, kepekaan lembaga pendidikan atau lembaga-lembaga sosial maupun profesional terhadap permasalahan hukum yang terjadi di masyarakat. Pemberian pendapat ataupun saran dapat dilakukan melalui cara langsung yaitu dengan turut serta secara keseluruhan maupun beberapa bagian saja dalam perumusan suatu peraturan daerah yang dilakukan baik oleh lembaga eksekutif maupun lembaga legislatif. Bentuk pemberian saran melalui cara tidak langsung yakni dengan melakukan suatu kegiatan yang sekiranya dapat memberikan pengaruh dalam proses pembentukan produk hukum tersebut, yakni contohnya adalah demonstrasi atau unjuk rasa. ${ }^{11}$

Dengan adanya suatu partisipasi publik, diharapkan suatu produk hukum akan memiliki manfaat keberlakuan di dalam masyarakat. Lain daripada itu, partisipasi juga memberikan dukungan politik dari masyarakat terhadap pembentukan produk hukum.Lembaga legislatif, yakni DPR/DPRD dituntut untuk membuka kesempatan yang seluas-luasnya bagi ruang partisipasi masyarakat.

\section{PENUTUP}

\subsection{Simpulan}

1. Dalam menegakkan hak asasi manusia, pada dasarnya merupakan bagian dari

\footnotetext{
11 IzaRumesten R.S, Model Ideal Partisipasi Masyarakat Dalam Pembentukan Peraturan Daerah, Jurnal Dinamika Hukum Vol. 12 No. 1 Januari 2012, hlm. 143.
} 
kebudayaan dan sejarah di berbagai negara, termasuk Indonesia. Menurut istilah Komisi Hukum Internasional, hak sipil dan politik menuntut tanggung jawab Negara dalam bentuk obligation of conduct. ICCPR adalah hak negatif yang termasuk hak-hak non deragable (hak absolute) yakni hak hidup, bebas dari perbudakan, penyiksaan, penahanan (karena utang), pidana berlaku surut, hak sebagai subyek hukum, dan hak kebebasan berfikir, dan hak-hak deragable, yakni hak berkumpul, hak berserikat, dan hak kebebasanmenyatakan pendapat. Terkait dengan kebebasan dalam penyampaian masukan dan saran oleh masyarakat dalam proses penyusunan suatu produk hukum, terdapat dalam beberapa peraturan hukum yakni Pasal 28 dan 28E ayat (3) UUD NRI Tahun 1945, Undang-Undang No. 9 Tahun 1998 tentang Kemerdekaan Menyampaikan Pendapat Di Muka Umum, Undang-Undang No. 39 Tahun 1999 tentang Hak Asasi Manusia, Undang-Undang No. 12 Tahun 2005 tentang Pengesahan Internasional Covenant On Civil And Political Rights (Covenant Internasional Tentang Hak-Hak Sipil Dan Politik) dan Pasal 96 UndangUndang Nomor 12 Tahun 2011
Tentang Pembentukan Peraturan Perundang-Undangan.

2. Titik tolak dari penyusunan peraturan daerah adalah partisipasi dari masyarakat. Adapun yang menjadi tujuan dari peran aktif masyarakat adalah untuk mendapatkan input dan pengalaman yang dapat digunakan dari berbagai elemen masyarakat yang memiliki kepentingan dalam upaya menaikkan kualitas suatu produk hukum, Dalam administrasi negara, khususnya dalam proses penyusunan suatu produk hukum, partisipasi masyarakat memiliki berbagai variasi tergantung tempat dan waktu, kondisi masyarakat danl ingkungannya Pemberian masukan dan saran dapat dilakukan melalui cara langsung yaitu dengan turut secara keseluruhan atau beberapa bagian dari proses perumusan perpu atau perda baik dilakukan melalui lembaga eksekutif atau legislatif. Partisipasi melalui cara tidak langsung yakni dengan melakukan suatu aktivitas yang sekiranya dapat memberi pandangan terhadap proses penyusunan produk hukum. Dimana cara biasa yang dapat dilakukan adalah demonstrasi atau unjuk rasa. 


\subsection{Saran}

Untuk lebih menggugah minat publik untuk berperan aktif dalam proses penyusunan produk hukum, terutama bagi masyarakat yang terkena langsung peraturan tersebut, penulis menyarankan agar dibentuk suatu panitia kerja khusus oleh pemerintah daerah. dimana tim tersebut bertugas terjun langsung ke masyarakat untuk mensosialisasikan dan menyampaikan program pemerintah sehingga diharapkan pemerintah dalam pembuat suatu produk hukum daerah benar-benar sesuai dengan kebutuhan rakyatnya yang nantinya peraturan tersebut diharapkan dapat berlaku secara efektif.

\section{DAFTAR BACAAN}

\section{Buku}

Achmad Ali, 2009, Menguak Teori Hukum (Legal Theory) dan Teori Peradilan (Judicial Prudence) Termasuk Interpretasi UndangUndang (Legisprudence), Prenada Media Group, Jakarta.

SatjiptoRaharjo, 2010, Sosiologi Hukum Perkembangan Metode dan Pilihan Masalah, Genta Publishing, Yogyakarta

Bagir Manan. 2001, Menyongsong Fajar Otonomi Daerah, PSH Fak. Hukum UIL Yogyakarta

H. Zainudin Ali, 2010, Metode Penelitian Hukum, Sinar Grafika, Jakarta

Iza Rumesten R.S, Model Ideal Partisipasi Masyarakat Dalam
Pembentukan Peraturan Daerah, Jurnal Dinamika Hukum Vol. 12 No. 1 Januari 2012.

Jack Donnely, 2003, Universal Human Rights in Theory and Practice $T^{d}$ Edition, Cornell University Press, New York.

Manfred Nowak, 2003, Pengantar Rezim Hak Asasi Manusia Internasional, (Alih Bahasa oleh Sri Sulastini), MartinusNijhoff Publisher, English.

Masyhur Effendi dan TaufaniSukmanaEvandri, 2007, HAMDalam Dimensi/Dinamika Yuridis, Sosial, Politik, Ghalia Indonesia, Bogor

Mahendra Putra Kurnia, dkk, 2007. Pedoman Naskah Akademik PerdaPartisipatif, Kreasi Total Media, Yogyakarta.

Roger Cotterrell, 2012, Sosiologi Hukum TheSosiology of Law, Diterjemahkan oleh NarulitaYusron, Nusa Media, Bandung.

\section{Peraturan Perundang-Undangan}

Undang-Undang Dasar Negara

Republik Indonesia Tahun 1945

Undang-Undang No. 9

Tahun 1998 tentang Kemerdekaan

Menyampaikan Pendapat Di Muka Umum, Lembaran Negara Republik Indonesia Tahun 1998 Nomor 181, Tambahan Lembaran Negara Republik Indonesia Nomor 3789

Undang-Undang No. 39 Tahun 1999 tentang Hak Asasi Manusia, Lembaran Negara Republik Indonesia 
Tahun 1999 Nomor 165, Tambahan Lembaran Negara Republik Indonesia Nomor 3886

Undang-Undang No. 12 Tahun

2005 tentang Pengesahan Internasional Covenant On Civil And Political Rights (Covenant Internasional Tentang Hak-Hak Sipil Dan Politik), Lembaran Negara Republik Indonesia Tahun 2005 Nomor 119, Tambahan Lembaran Negara Republik Indonesia Nomor 4558

Undang-Undang Nomor

12 Tahun $2011 \quad$ Tentang

Pembentukan Peraturan PerundangUndangan,Lembaran Negara Republik Indonesia Tahun 2011 Nomor 82, Tambahan Lembaran Negara Republik Indonesia Nomor 5234. 